\title{
Protective role of propolis on low and high dose furan-induced hepatotoxicity and oxidative stress in rats
}

\author{
Emre Kaya $^{1}$, Seval Y1lmaz ${ }^{1}$, Songul Ceribasi ${ }^{2}$ \\ ${ }^{1}$ Department of Biochemistry, ${ }^{2}$ Department of Pathology, Faculty of Veterinary Medicine, \\ Firat University, 23119, Elaziğ, Turkey \\ emre_57000@hotmail.com
}

Received: February 13, 2019 Accepted: August 12, 2019

\begin{abstract}
Introduction: The aim of this study was to evaluate potential protective effects of propolis on furan-induced hepatic damage by assessing the levels of malondialdehyde (MDA) and reduced glutathione (GSH), antioxidant enzyme activities, and histopathological changes in the liver. Material and Methods: Albino Wistar rats were divided into six groups: a control, propolis-treated (100 mg/kg b.w./day), low-dose furan-treated (furan-L group; $2 \mathrm{mg} / \mathrm{kg} \mathrm{b.w./day),} \mathrm{high-dose} \mathrm{furan-treated}$ (furan-H group; $16 \mathrm{mg} / \mathrm{kg}$ b.w./day), furan-L+propolis treated, and furan-H+propolis treated group. Propolis and furan were applied by gavage; propolis for 8 days, and furan for 20 days in furan-L groups and 10 days in furan-H groups. Results: While MDA levels were elevated in furan-treated groups, levels of GSH and activities of antioxidant enzymes decreased $(p<0.001)$. The levels of MDA and GSH and activities of antioxidant enzymes were normal in the furan+propolis groups, especially in the furan- $\mathrm{L}+$ propolis group $(\mathrm{p}<0.001)$. While the aspartate transaminase, alanine transaminase, alkaline phosphatase, and lactate pdehydrogenase activities were elevated in the furan- $\mathrm{H}$ treated group $(\mathrm{p}<0.05$ and $\mathrm{p}<0.001)$, they were unchanged in the furan-L treated group. Histopathologically, several lesions were observed in the liver tissues of the furan-treated groups, especially in the higher-dose group. It was determined that these changes were milder in both of the furan+propolis groups. Conclusion: The results indicate that propolis exhibits good hepatoprotective and antioxidant potential against furan-induced hepatocellular damage in rats.
\end{abstract}

Keywords: rats, furan, hepatotoxicity, oxidative stress, propolis.

\section{Introduction}

Furan is a colourless, volatile, and lipophilic compound which is used as an intermediate product in the synthesis of many chemical and pharmaceutical agents, solvents, lacquers, and resins. Furan has been demonstrated to derive from temperaturedegraded/reduced sugars alone by the Maillard reaction, or it may be formed in the presence of temperature-degraded or unaltered amino acids and by the oxidation of ascorbic acid, unsaturated multiple fatty acids, and carotenoids at the appropriate temperature (Fig. 1) (31).

This chemical and many of its compounds are highly toxic and are associated with serious health effects including cancer, hormonal imbalances, immune system irregularities, and growth rate and behavioural disorders. In addition to these deleterious postnatal effects on human health, another major concern are furan-associated developmental disorders in the foetus (18).

Furan is an important industrial compound primarily used as a solvent and as an intermediate product in the synthesis of other furan-containing chemicals. It is widely available in the environment and has been found in almost all components of the ecosystem, such as air, water, soil, and sediments. This toxic substance quickly accumulates in the food chain and has been detected in a broad variety of foods, particularly coffee, canned meat products, and baby food, with levels exceeding $100 \mathrm{ppb}$. 


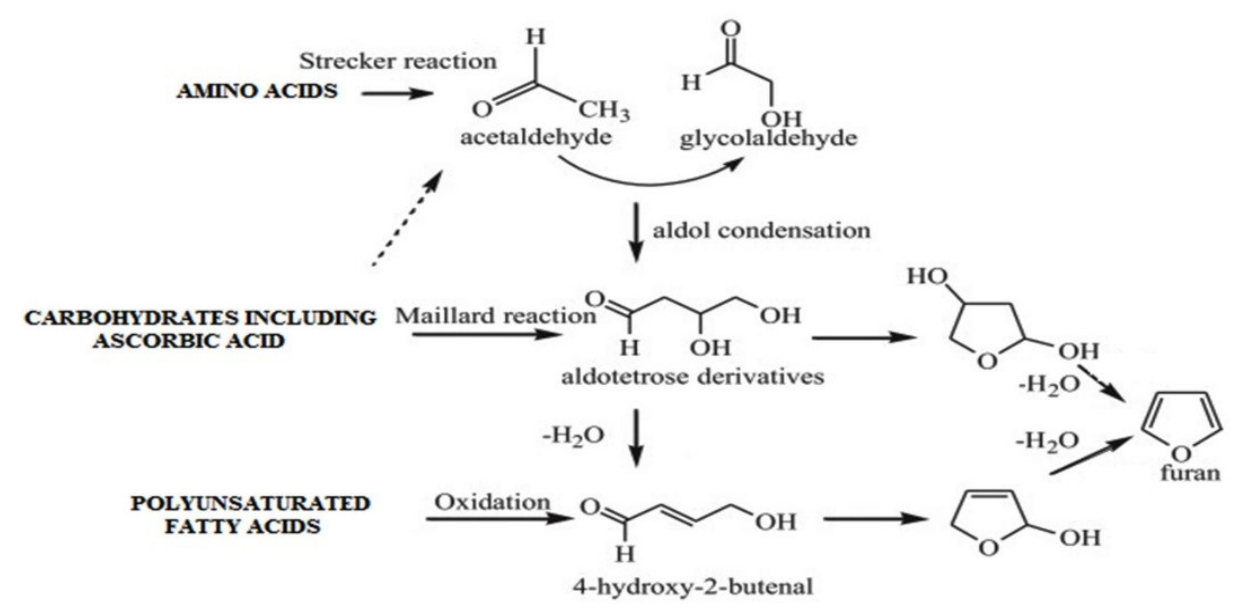

Fig. 1. Different origins of furan (adapted from Perez-Locas and Yaylayan (31))

A survey of food samples was performed and it was demonstrated that furan occurs at levels $>100 \mu \mathrm{g} / \mathrm{g}$ in a wide range of foods, including wheat, bread, cooked meat products, and roasted coffee (5). It is readily transferred to mammals, accumulates in their fat tissues for many years, passes into the circulating blood as a result of stress or hunger, and continues to have toxic effects (46).

Laboratory studies on animals have shown that furan is highly toxic even at low concentrations (9). Wilson et al. (44) found that furan evoked hepatic necrosis and cell proliferation at the highest doses both in mice $(15 \mathrm{mg} / \mathrm{kg})$ and rats $(8 \mathrm{mg} / \mathrm{kg})$. In the toxicity risk assessment published by the European Food and Safety Authority (EFSA), furan was reported to be carcinogenic in rats and mice above a certain dose, most likely through affecting the genotoxic mechanisms (15). Furan has been classified as possibly carcinogenic for humans (Group 2B) by the International Agency for Research on Cancer (IARC) as it is carcinogenic in rats and mice (20).

Furan and its compounds are cytotoxic and cause necrosis in their respective target organs, most frequently in the liver, kidneys, and lungs. These target organs contain cells (hepatocytes, tubule epithelial cells and Clara cells) which express high levels of cytochrome P450 mixed-function oxidase activity. Prior administration of compounds which induce mixed-function oxidase activity markedly increases the severity of target organ necrosis associated with exposure to furan (8).

Oxidative stress exists in a cell or tissue when the concentration of reactive oxygen species (ROS) generated exceeds the antioxidant capability of that cell. Antioxidants have the ability to reduce oxidative damage by either induction or inhibition of key enzyme systems. It is thought that furan can interact with the antioxidant system in cells and tissues and cause free radicals to form. ROS are naturally generated by living organisms. Under normal physiological conditions, there is a balance between the ROS formation rate and enzymatic activities, including catalase (CAT), glutathione peroxidase (GSH-Px), glutathione-Stransferase (GST), and superoxide dismutase (SOD). The ROS formation rate is also balanced with the nonenzymatic antioxidants such as glutathione (GSH) and vitamins $\mathrm{A}, \mathrm{E}$, and $\mathrm{C}$. Oxidative stress occurs when the balance is impaired due to excessive amounts of ROS generation and/or inadequate antioxidant defence. Lipid peroxidation is the greatest indicator of oxidative stress. Malondialdehyde (MDA) is the best-established and simplest parameter to be tested for determining the extent of lipid peroxidation under oxidative stress conditions, and provides relevant results for clinical practice (47).

Propolis is a sticky and resinous substance collected by honey bees (Apis mellifera L.) from various plants. It protects the hive from external factors, microorganisms, and other harmful substances. Natural in origin, propolis is a product widely used in folk remedies. It contains more than 150 polyphenol compounds such as flavonoids and phenolic acid, including their esters (48). Various in vivo and in vitro studies have shown that the biological activities of propolis include free radical scavenging (30), as well as antioxidant, antitumour, antimicrobial, antiviral, anti-inflammatory, local anaesthetic, and immunomodulatory effects. These properties of propolis have been associated with its rich content in flavonoids, phenolic acids, and terpenoids (48). Takino and Mochida (40) have stated that the biological activity of propolis is mainly dependent on its flavonoid content. Propolis was proposed to be a naturally hepatoprotective product, and in many studies, it has been shown to protect the liver against toxicity, thereby preventing harm to the main organ responsible for the biotransformation of different components and many harmful chemical substances (1, 3, 4, 7, 13, 23). Propolis creates a hepatoprotective effect by increasing the total protein and $\gamma$-globulin content in the liver. It also has a role in the elimination of tissue damage in 
the liver by increasing protein synthesis in hepatocytes and regulating the content of GSH in the cells $(4,30)$.

The aim of this present study was to investigate whether the administration of propolis to rats would display any protective effects against furan-induced hepatotoxicity by means of evaluating biochemically and histopathologically derived data.

\section{Material and Methods}

Experimental design. A total of 42 healthy male albino Wistar rats (12 weeks old, weighing 250-300 g) were used. Rats were fed a standard rat pellet diet and tap water was provided ad libitum. Housing conditions were those of a standard laboratory, including the maintenance of the temperature at $24 \pm 3^{\circ} \mathrm{C}$ with light and dark cycles of $12 \mathrm{~h}$ each.

Rats were randomly divided into equal six groups: a control group, propolis-treated group $(100 \mathrm{mg} / \mathrm{kg}$ b.w./day), low-dose furan-treated group (furan-L group, $2 \mathrm{mg} / \mathrm{kg}$ b.w./day), high-dose furan treated group (furan- $\mathrm{H}$ group, $16 \mathrm{mg} / \mathrm{kg}$ b.w./day), furan$\mathrm{L}+$ propolis treated group, and furan $-\mathrm{H}+$ propolis treated group. The rats in the control group did not receive any treatment. Furan was administered by gavage for 20 days in the furan- $\mathrm{L}$ groups and for 10 days in the furan- $\mathrm{H}$ groups. Propolis was given simultaneously with furan administration and was also administered by gavage, in this case for eight days. The doses of propolis and furan used were selected by the precedents in the literature $(11,13)$.

Biochemical analysis. The rats were sacrificed and liver samples were taken at the end of the experiment. Prior to the analyses, the collected liver tissues were washed with physiological saline solution, diluted at a ratio of 1:10 with distilled water, and homogenised in a Potter-Elvehjem homogeniser (CAT R50D, Germany). The homogenate was centrifuged at $4^{\circ} \mathrm{C}$ at $3,000 \mathrm{~g}$ for $15 \mathrm{~min}$ to quantify MDA, GSH, CAT, GST, and SOD, and at 10,000 $\mathrm{g}$ for $55 \mathrm{~min}$ to test the amount of GSH-Px.

The MDA level was tested according to the method described by Placer et al. (33). This method was based on the reaction of thiobarbituric acid with MDA, one of the aldehyde products of lipid peroxidation. The GSH level was determined by the method of Ellman et al. (14). This method was spectrophotometric and based on the formation of a highly stable yellow colour in sulphhydryl groups when 5,5'-dithiobis-2-nitrobenzoic acid (DTNB) was added. The CAT activity was revealed by using Aebi's method (2). It was determined by measuring the resolution of hydrogen peroxide $\left(\mathrm{H}_{2} \mathrm{O}_{2}\right)$ at $240 \mathrm{~nm}$. Measuring of GSH-Px activity was by the Beutler method (6). GSH-Px catalyses the oxidation of GSH to oxide glutathione (GSSG) using $\mathrm{H}_{2} \mathrm{O}_{2}$. The rate of formation of GSSG was measured by the glutathione reductase reaction. The method described by Habig et al. (17) was utilised to test GST activity. The enzyme activity was determined by measuring the amount of enzyme catalysing $1 \mu \mathrm{mol}$ of 1 -(S-glutathionyl)-2,4 dinitrobenzene per minute at $340 \mathrm{~nm}$ at $37^{\circ} \mathrm{C}$ using GSH and 1-chloro-2,4-dinitrobenzene. Quantifying superoxide anion $\left(\mathrm{O}_{2}^{-}\right)$generation provided data for SOD activity, where generation was by xanthine and xanthine oxidases reacting with nitroblue tetrazolium (39). The determination of protein concentration was performed using the method described by Lowry et al. (26). Plasma was used to determine aspartate transaminase (AST), alanine transaminase (ALT), alkaline phosphatase (ALP), and lactate dehydrogenase (LDH) activities and cholesterol levels with the use of an Advia 1800 Chemistry Analyser (Siemens Healthineers, Germany).

Histopathological examination. The liver samples were fixed in 10\% neutral buffered formalin, embedded in paraffin blocks, cut to $5 \mu \mathrm{m}$ slices, and stained with haematoxylin and eosin (HE), and then examined under a light microscope (27). For the histopathological evaluation, 10 randomly selected microscopic fields were examined.

Statistical analysis. The results were expressed as mean \pm standard error (SE). The Shapiro-Wilk normality test was used to determine whether the raw values of all the measured parameters showed normal distribution. The values yielded by the test all showed normal distribution. ANOVA was used to reveal whether significant differences existed among the groups. A post hoc Tukey test was used for multiple intergroup comparisons. Statistical significance was accepted at $p<0.05$. The Statistical Package for Social Sciences (SPSS) PC software programme (version 22.0; IBM, USA) was used to perform the statistical analysis of the data.

\section{Results}

Biochemical results. Table 1 presents the levels of MDA and GSH and the activities of antioxidant enzymes (CAT, GSH-Px, GST, and SOD) in the livers of the control and experimental groups. While MDA levels were increased in the furan-treated groups, the level of GSH and activities of CAT, GSH-Px, GST, and SOD were decreased $(\mathrm{p}<0.001)$. A comparison of the furan-L and furan-H groups demonstrated that changes in the MDA and GSH levels were more pronounced in the furan-H group, while no changes were observed in the activities of CAT, GSH-Px, GST, or SOD. The MDA and GSH levels and the CAT and GSH-Px activities were found to be close to control group values in the furan+propolis groups $(\mathrm{p}<0.001)$. The GST and SOD activities were close to control group values in the furan-L+propolis group. In the high-dose furan and propolis combination group (furan$\mathrm{H}+$ propolis), GST and SOD were more highly active than in the furan-only groups; however, they did not 
fully match levels in the control group. There were no statistically significant differences between the propolistreated groups and furan+propolis-treated groups.

Plasma AST, ALT, ALP, and LDH activities and cholesterol levels. Table 2 shows the biochemical parameters of plasma AST, ALT, ALP, and LDH activities and cholesterol levels in the control and experimental groups. There was no statistical difference between the control and propolis groups in these biochemical parameters. While the AST, ALT, ALP, and LDH activities were elevated in the furan-H treated group $(\mathrm{p}<0.05$ and $\mathrm{p}<0.001)$, there were no changes in the furan-L treated group compared with the control group. Plasma cholesterol levels were not statistically different among all groups. The plasma AST, ALT, ALP, and LDH activities were not statistically different between the furan-L+propolis group and the furan-L group. While the plasma AST and ALT were less active, ALP and LDH activities were comparable in the furan-H-treated and furan$\mathrm{H}+$ propolis-treated groups.

Histopathological results. Microscopic changes observed in control and experimental groups are shown in Table 3. Histological structures of liver tissues of the control- and propolis-treated groups were normal, and the most severe lesions were noticed in the furan-H group. Generally, karyomegaly, pseudo-inclusion and atypia in hepatocyte nuclei were the prominent changes in all experimental groups. Cloudy swelling was markedly degenerative in all experimental groups, while macrovesicular fatty change was detected in the furan-H group, moderate fat deposition was found in the furan- $\mathrm{L}$ and furan- $\mathrm{H}+$ propolis groups, and light fat deposition was in evidence in the furan- $\mathrm{L}+$ propolis group. Fibrotic changes were usually evident in the periportal region in all experimental groups, but capsular fibrosis was also observed in the furan-H and furan-H+propolis groups. The most severe bile duct proliferation was seen in the furan- $\mathrm{L}$ and furan- $\mathrm{H}$ groups, but the severity of this lesion type was less in groups where furan and propolis were applied together. Similarly, the severity of periportal cell infiltration, single cell necrosis, and bile pigment accumulation was also attenuated in groups where furan and propolis were applied together (Figs 2 and 3).

Table 1. The effect of propolis supplementation on liver MDA and GSH levels and CAT, GSH-Px, GST, and SOD activities

\begin{tabular}{|c|c|c|c|c|c|c|}
\hline & Control & Propolis & Furan-L & Furan-H & Furan-L+ Prop. & Furan-H+ Prop. \\
\hline $\begin{array}{l}\text { MDA } \\
\text { (nmol/g tissue) }\end{array}$ & $0.62 \pm 0.02^{\mathrm{c}}$ & $0.59 \pm 0.02^{\mathrm{c}}$ & $0.79 \pm 0.04^{\mathrm{b}}$ & $0.90 \pm 0.05^{\mathrm{a}}$ & $0.67 \pm 0.03^{\mathrm{c}}$ & $0.67 \pm 0.01^{\mathrm{c}}$ \\
\hline $\begin{array}{l}\text { GSH } \\
(\mu \mathrm{mol} / \mathrm{ml})\end{array}$ & $23.71 \pm 0.30^{\mathrm{a}}$ & $23.99 \pm 0.21^{\mathrm{a}}$ & $22.48 \pm 0.35^{\mathrm{b}}$ & $21.25 \pm 0.30^{\mathrm{c}}$ & $23.40 \pm 0.24^{\mathrm{a}}$ & $23.39 \pm 0.29^{\mathrm{a}}$ \\
\hline $\begin{array}{l}\text { CAT } \\
\text { (k/mg protein) }\end{array}$ & $0.260 \pm 0.02^{\mathrm{a}}$ & $0.241 \pm 0.01^{\mathrm{a}}$ & $0.113 \pm 0.02^{\mathrm{b}}$ & $0.042 \pm 0.01^{\mathrm{b}}$ & $0.234 \pm 0.02^{\mathrm{a}}$ & $0.238 \pm 0.01^{\mathrm{a}}$ \\
\hline $\begin{array}{l}\text { GSH-Px } \\
\text { (U/g protein) }\end{array}$ & $48.34 \pm 2.83^{\mathrm{a}}$ & $47.44 \pm 2.09^{\mathrm{a}}$ & $25.79 \pm 2.42^{\mathrm{b}}$ & $29.46 \pm 0.82^{b}$ & $42.27 \pm 1.16^{\mathrm{a}}$ & $42.39 \pm 2.46^{\mathrm{a}}$ \\
\hline $\begin{array}{l}\text { GST } \\
\text { (U/mg protein) }\end{array}$ & $23.19 \pm 0.84^{\mathrm{a}}$ & $21.05 \pm 0.80^{\mathrm{ab}}$ & $14.96 \pm 0.84^{\mathrm{c}}$ & $13.87 \pm 1.02^{\mathrm{c}}$ & $21.03 \pm 0.90^{\mathrm{ab}}$ & $19.97 \pm 1.19^{\mathrm{b}}$ \\
\hline $\begin{array}{l}\text { SOD } \\
\text { (U/g protein) }\end{array}$ & $77.49 \pm 0.25^{\mathrm{a}}$ & $77.19 \pm 0.31^{\mathrm{ab}}$ & $74.18 \pm 0.22^{\mathrm{c}}$ & $73.00 \pm 0.58^{c}$ & $76.10 \pm 0.27^{\mathrm{ab}}$ & $75.83 \pm 0.81^{\mathrm{b}}$ \\
\hline
\end{tabular}

The data are expressed as mean \pm SE for seven animals per group. Within rows, means with different letters $(a, b$, and $c)$ are significantly different $(\mathrm{p}<0.001)$

Table 2. The effect of propolis supplementation on plasma AST, ALT, ALP, and LDH activities and cholesterol levels

\begin{tabular}{|c|c|c|c|c|c|c|}
\hline & Control & Propolis & Furan-L & Furan-H & Furan-L+ Prop. & Furan-H+ Prop. \\
\hline $\begin{array}{l}\mathrm{AST} \\
(\mathrm{U} / \mathrm{L})\end{array}$ & $212.66 \pm 22.09^{b c}$ & $192.0 \pm 12.49^{\mathrm{c}}$ & $236.00 \pm 10.56^{\mathrm{bc}}$ & $639.00 \pm 27.71^{\mathrm{a}^{* *}}$ & $192.66 \pm 20.52^{\mathrm{c}}$ & $261.00 \pm 16.74^{b}$ \\
\hline $\begin{array}{l}\text { ALT } \\
(\mathrm{U} / \mathrm{L})\end{array}$ & $55.66 \pm 2.69^{c}$ & $52.33 \pm 3.65^{\mathrm{c}}$ & $62.00 \pm 4.70^{\mathrm{c}}$ & $281.0 \pm 3.46^{6^{* *}}$ & $42.33 \pm 1.72^{c}$ & $124.50 \pm 4.53^{b}$ \\
\hline $\begin{array}{l}\text { ALP } \\
(\mathrm{U} / \mathrm{L})\end{array}$ & $6.66 \pm 0.21^{\mathrm{c}}$ & $5.33 \pm 0.55^{\mathrm{c}}$ & $7.00 \pm 0.80^{\mathrm{bc}}$ & $9.50 \pm 0.28^{\mathrm{a}^{*}}$ & $6.00 \pm 0.36^{\mathrm{c}}$ & $8.50 \pm 0.28^{\mathrm{ab}}$ \\
\hline $\begin{array}{l}\mathrm{LDH} \\
(\mathrm{U} / \mathrm{L})\end{array}$ & $969.00 \pm 143.21^{\mathrm{b}}$ & $804.50 \pm 112.87^{\mathrm{b}}$ & $957.50 \pm 32.75^{\mathrm{b}}$ & $1647.33 \pm 245.63^{\mathrm{a}^{* *}}$ & $768.50 \pm 101.32^{b}$ & $1557.50 \pm 115.75^{\mathrm{a}}$ \\
\hline $\begin{array}{l}\text { Cholesterol } \\
(\mathrm{mg} / \mathrm{dL})\end{array}$ & $50.66 \pm 0.84$ & $47.00 \pm 2.19$ & $56.75 \pm 2.89$ & $57.00 \pm 1.15$ & $45.66 \pm 1.87$ & $47.00 \pm 1.15$ \\
\hline
\end{tabular}

The data are expressed as mean \pm SE for seven animals per group. Within rows, means with different letters (a, b, and c) are significantly different $(* \mathrm{p}<0.05, * * \mathrm{p}<0.001)$ 

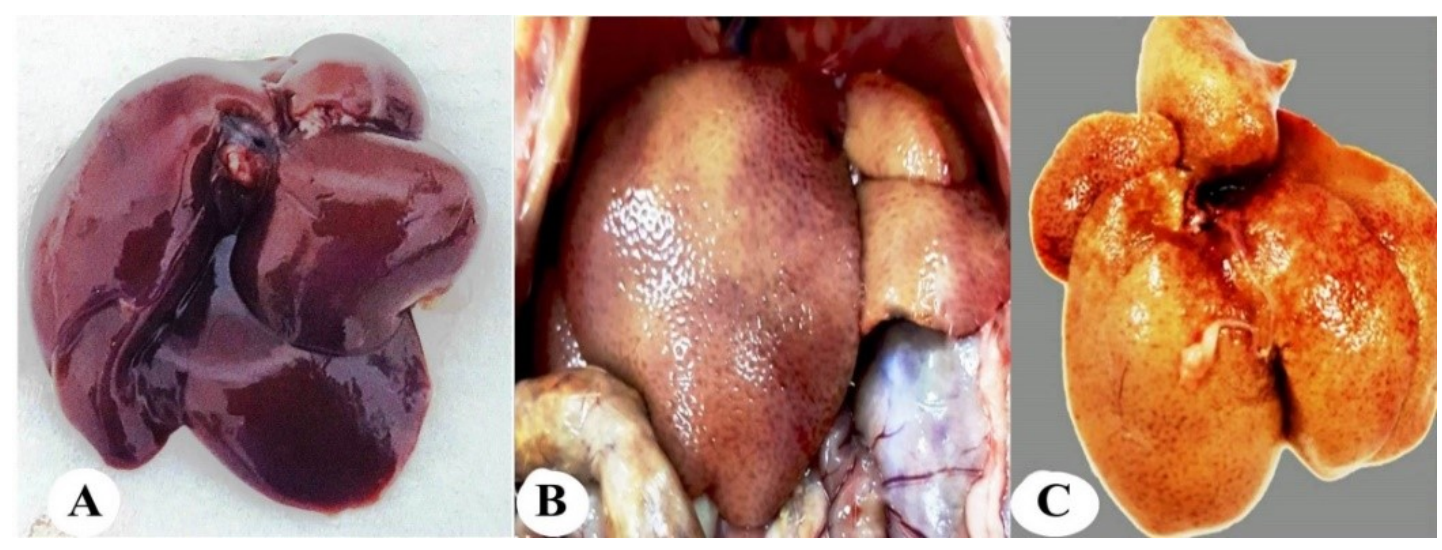

Fig. 2. The livers of furan-treated rats. A - normal macroscopic view of the liver in the control group. B - focal congestion and pale yellow surface in the furan-L group. $\mathrm{C}$ - appearance of enlarged pale yellow liver with a rounded edge in the furan- $\mathrm{H}$ group

Table 3. The effect of propolis supplementation on liver histopathological changes

\begin{tabular}{|c|c|c|c|c|c|c|}
\hline & Control & Propolis & Furan-L & Furan-H & $\begin{array}{l}\text { Furan-L+ } \\
\text { Propolis }\end{array}$ & $\begin{array}{l}\text { Furan-H+ } \\
\text { Propolis }\end{array}$ \\
\hline Oval cell proliferation & $0.0 \pm 0.0^{\mathrm{d}}$ & $0.0 \pm 0.0^{\mathrm{d}}$ & $1.67 \pm 0.33^{b}$ & $3.00 \pm 0.0^{\mathrm{a}}$ & $0.0 \pm 0.0^{\mathrm{d}}$ & $1.00 \pm 0.0^{\mathrm{c}}$ \\
\hline Pseudo-inclusion & $0.0 \pm 0.0^{\mathrm{d}}$ & $0.0 \pm 0.0^{\mathrm{d}}$ & $1.00 \pm 0.0^{\mathrm{b}}$ & $2.00 \pm 0.0^{\mathrm{a}}$ & $0.33 \pm 0.21^{\mathrm{c}}$ & $1.00 \pm 0.0^{\mathrm{b}}$ \\
\hline Nuclear atypia & $0.0 \pm 0.0^{\mathrm{b}}$ & $0.0 \pm 0.0^{\mathrm{b}}$ & $1.33 \pm 0.21^{\mathrm{a}}$ & $1.50 \pm 0.22^{\mathrm{a}}$ & $0.33 \pm 0.21^{\mathrm{b}}$ & $1.00 \pm 0.0^{\mathrm{a}}$ \\
\hline Karyomegaly & $0.0 \pm 0.0^{\mathrm{c}}$ & $0.0 \pm 0.0^{\mathrm{c}}$ & $1.17 \pm 0.17^{\mathrm{ab}}$ & $1.50 \pm 0.22^{\mathrm{a}}$ & $1.00 \pm 0.0^{\mathrm{b}}$ & $1.00 \pm 0.0^{\mathrm{b}}$ \\
\hline Macrovesicular fatty & $0.0 \pm 0.0^{\mathrm{c}}$ & $0.0 \pm 0.0^{\mathrm{c}}$ & $1.00 \pm 0.37^{b}$ & $3.00 \pm 0.0^{\mathrm{a}}$ & $0.67 \pm 0.21^{\mathrm{b}}$ & $1.00 \pm 0.0^{\mathrm{b}}$ \\
\hline Apoptotic body & $0.0 \pm 0.0^{\mathrm{d}}$ & $0.0 \pm 0.0^{\mathrm{d}}$ & $1.33 \pm 0.21^{\mathrm{b}}$ & $2.00 \pm 0.0^{\mathrm{a}}$ & $1.00 \pm 0.0^{\mathrm{c}}$ & $2.00 \pm 0.0^{\mathrm{a}}$ \\
\hline Periportal fibrosis & $0.0 \pm 0.0^{\mathrm{c}}$ & $0.0 \pm 0.0^{\mathrm{c}}$ & $1.33 \pm 0.21^{\mathrm{b}}$ & $2.50 \pm 0.22^{\mathrm{a}}$ & $1.00 \pm 0.0^{\mathrm{b}}$ & $1.00 \pm 0.0^{\mathrm{b}}$ \\
\hline Pericentral fibrosis & $0.0 \pm 0.0^{\mathrm{c}}$ & $0.0 \pm 0.0^{\mathrm{c}}$ & $0.33 \pm 0.21^{\mathrm{bc}}$ & $0.50 \pm 0.22^{\mathrm{b}}$ & $0.0 \pm 0.0^{\mathrm{c}}$ & $1.00 \pm 0.0^{\mathrm{a}}$ \\
\hline Capsular fibrosis & $0.0 \pm 0.0^{\mathrm{b}}$ & $0.0 \pm 0.0^{\mathrm{b}}$ & $0.17 \pm 0.17^{b}$ & $1.00 \pm 0.45^{\mathrm{a}}$ & $0.33 \pm 0.21^{\mathrm{ab}}$ & $1.00 \pm 0.0^{\mathrm{a}}$ \\
\hline Bile duct proliferation & $0.0 \pm 0.0^{\mathrm{d}}$ & $0.0 \pm 0.0^{\mathrm{d}}$ & $1.67 \pm 0.21^{b}$ & $3.00 \pm 0.0^{\mathrm{a}}$ & $1.00 \pm 0.0^{\mathrm{c}}$ & $1.00 \pm 0.0^{\mathrm{c}}$ \\
\hline Nodule (adenoma) & $0.0 \pm 0.0^{\mathrm{b}}$ & $0.0 \pm 0.0^{\mathrm{b}}$ & $0.17 \pm 0.17^{\mathrm{ab}}$ & $0.50 \pm 0.22^{\mathrm{a}}$ & $0.0 \pm 0.0^{\mathrm{b}}$ & $0.0 \pm 0.0^{\mathrm{b}}$ \\
\hline Sinusoidal congestion & $0.0 \pm 0.0^{\mathrm{d}}$ & $0.0 \pm 0.0^{\mathrm{d}}$ & $1.50 \pm 0.22^{\mathrm{b}}$ & $2.00 \pm 0.0^{\mathrm{a}}$ & $1.33 \pm 0.21^{\mathrm{bc}}$ & $1.00 \pm 0.0^{\mathrm{c}}$ \\
\hline Periportal cell infiltration & $0.0 \pm 0.0^{\mathrm{e}}$ & $0.0 \pm 0.0^{\mathrm{e}}$ & $1.50 \pm 0.22^{\mathrm{c}}$ & $2.50 \pm 0.22^{\mathrm{a}}$ & $1.00 \pm 0.0^{\mathrm{d}}$ & $2.00 \pm 0.0^{\mathrm{b}}$ \\
\hline Single cell necrosis & $0.0 \pm 0.0^{\mathrm{d}}$ & $0.0 \pm 0.0^{\mathrm{d}}$ & $1.50 \pm 0.22^{\mathrm{b}}$ & $2.00 \pm 0.0^{\mathrm{a}}$ & $0.67 \pm 0.21^{\mathrm{c}}$ & $1.00 \pm 0.0^{\mathrm{c}}$ \\
\hline Bile pigment accumulation & $0.0 \pm 0.0^{\mathrm{c}}$ & $0.0 \pm 0.0^{\mathrm{c}}$ & $1.00 \pm 0.37^{b}$ & $2.00 \pm 0.0^{\mathrm{a}}$ & $0.67 \pm 0.21^{\mathrm{b}}$ & $1.00 \pm 0.0^{\mathrm{b}}$ \\
\hline Sinusoidal congestion & $0.0 \pm 0.0^{\mathrm{c}}$ & $0.0 \pm 0.0^{\mathrm{c}}$ & $1.00 \pm 0.0^{\mathrm{a}}$ & $1.00 \pm 0.0^{\mathrm{a}}$ & $0.67 \pm 0.21^{\mathrm{b}}$ & $1.00 \pm 0.0^{\mathrm{a}}$ \\
\hline Parenchyma degeneration & $0.0 \pm 0.0^{\mathrm{c}}$ & $0.0 \pm 0.0^{\mathrm{c}}$ & $1.50 \pm 0.22^{\mathrm{b}}$ & $2.00 \pm 0.0^{\mathrm{a}}$ & $1.33 \pm 0.21^{\mathrm{b}}$ & $2.00 \pm 0.0^{\mathrm{a}}$ \\
\hline $\begin{array}{l}\text { Intestinal metaplasia in the } \\
\text { bile duct epithelium }\end{array}$ & $0.0 \pm 0.0^{\mathrm{b}}$ & $0.0 \pm 0.0^{\mathrm{b}}$ & $0.0 \pm 0.0^{\mathrm{b}}$ & $0.50 \pm 0.24^{\mathrm{a}}$ & $0.0 \pm 0.0^{\mathrm{b}}$ & $0.0 \pm 0.0^{\mathrm{b}}$ \\
\hline
\end{tabular}

The data are expressed as mean \pm SE for seven animals per group. Within rows, means with different letters (a, b, c, d, and e) are significantly different 

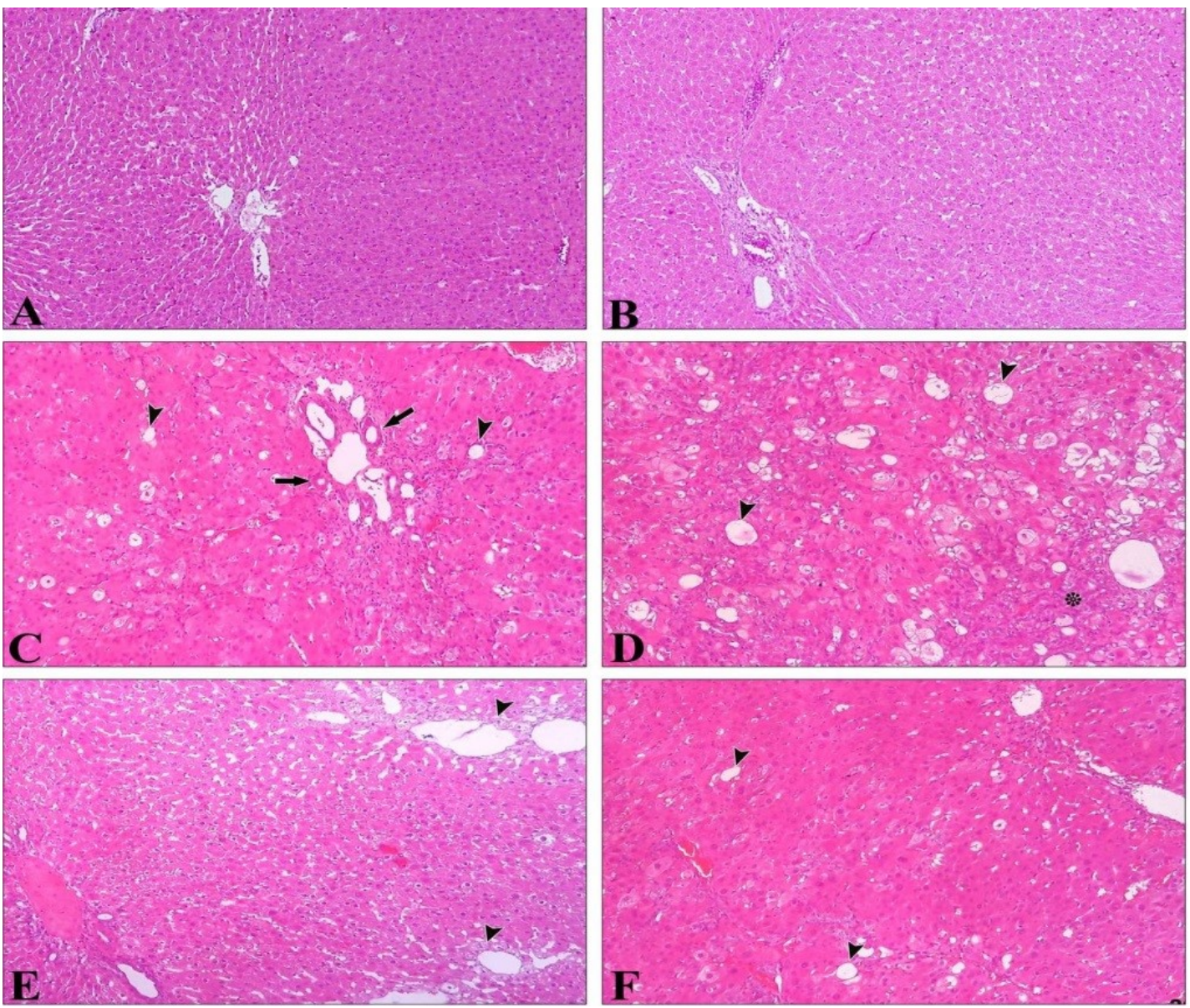

Fig. 3. A - control group: normal histological appearance of the liver. B - propolis group: normal histological appearance of the liver. C - furan-L group: slight macrovesicular lubrication in hepatocytes (arrowheads), periportal fibrosis and bile duct proliferation. D - furan-H group: severe and diffuse macrovesicular lubrication in hepatocytes (arrowheads), oval cell proliferation (*) and severe diffuse fibrosis in the liver parenchyma. E - furan-L+propolis group: cloudy swelling in pericentrally located hepatocytes (arrowheads). F - furan-H+propolis group: slight macrovesicular lubrication in hepatocytes (arrowheads) and mild periportal fibrosis. (HE, 50×)

\section{Discussion}

Besides being manufactured as a major industrial product, furan is generated unintentionally in processed food exposed to heat (canning, pasteurisation, etc.). It has recently been detected in a number of heatprocessed food items, including baby food (16). Sprankle et al. (38) have reported that it is also present in cigarette smoke.

According to the toxicity risk assessment published by EFSA, furan has been reported to be carcinogenic in rats at higher doses, possibly by affecting the genotoxic mechanisms (15). The toxicity and carcinogenicity of furan are mediated by the catalysis of cytochrome P450 (mostly CYP2E1), which is responsible for furan oxidation. Cytochrome P450 inducers aggravate the toxic effects of furan by metabolising it, and consequently furan-induced protein binding, GSH depletion, and cytotoxicity occur. These toxic effects are alleviated in the presence of cytochrome P450 inhibitors (32).

Cordelli et al. (10) investigated the toxic and genotoxic effects of orally administered furan $(2,4,8$, and $15 \mathrm{mg} / \mathrm{kg} / \mathrm{b}$.w.) on the liver tissues of mice. They reported that irregular areas of necrosis were observed in the liver parenchyma of the two experimental groups receiving high doses of furan ( 8 and $15 \mathrm{mg} / \mathrm{kg} / \mathrm{b}$.w.). Additionally, they observed occasional necrotic areas surrounded by hepatocytes with highly eosinophilic cytoplasm and hyperchromatic nuclei. Selmanoğlu et al. (37) investigated the effects of orally administered furan $(2,4$, and $8 \mathrm{mg} / \mathrm{kg} /$ day) on the liver and kidneys in growing rats. In histopathological examination, they observed hyperaemic blood vessels, congestion, oedema, and fibrosis in the liver of rats treated with furan.

Furan has been reported to be associated with the development of liver tumours, as hepatocellular carcinoma and cholangiocarcinoma, in male and female rats at doses of 2,4 , or $8 \mathrm{mg} / \mathrm{kg}$ b.w. administered five days a week for two years (29). Male rats treated with $30 \mathrm{mg} / \mathrm{kg} \mathrm{b}$.w. of furan for 3 months were reported to develop cholangiofibrosis, which in some cases progressed to tumours after 9 or 15 months without further treatment (28). National Toxicology Program (NTP) studies have shown that a 13-week 
administration of furan in animals caused weight loss and exerted potentially carcinogenic toxic effects on several organs such as weight increases in the liver, kidneys, and thymus and dose-related liver and kidney lesions. Ploch and Kedderis (34) reported that furanadministered mice developed necrosis in the liver and kidneys. No tumour-inducing effects were reported at doses $<2 \mathrm{mg} / \mathrm{kg}$ b.w.

Oxidative stress is a condition that is exacerbated proportionally to the amount of ROS generated in the environment. Overproduction of ROS in relation to furan leads to significant oxidative stress, cellular damage, and necrosis caused by various mechanisms including peroxidation of membrane lipids, protein denaturation, and DNA damage (19). Various studies demonstrate that exposure to furan increases intracellular ROS production and that the consequent biochemical and physiological disorders may be due to the emergent oxidative stress. It has been shown that furan can serve as an oxidant precursor; it reduces the activity levels of several antioxidant enzymes by inducing oxidative stress and increases lipid peroxidation in vital organs $(21,36,41,42)$.

Selmanoğlu et al. (37) conducted a furan study aiming to determine the level of oxidative stress in the rat liver and reported that there were no statistically significant changes in the activities of SOD or CAT, nor in MDA levels in the homogenates of livers systemically exposed to furan $(2,4$, and $8 \mathrm{mg} / \mathrm{kg} / \mathrm{day})$. Based on the MDA levels, they suggested that furan did not induce lipid peroxidation in the liver. In contrast, Dong et al. (12) showed that furan-induced (0.03, 0.12, 0.5 , or $2 \mathrm{mg} / \mathrm{kg} \mathrm{b.w./day} \mathrm{by} \mathrm{oral} \mathrm{gavage} \mathrm{for} 90$ days) liver tumours occurred in male rats and the key findings were alterations in gene expression associated with oxidative stress. Yuan et al. (49) and Wang et al. (43) showed that furan caused oxidative stress in association with elevated MDA levels and resulted in changes in antioxidant enzyme activities in mice. Similarly, in our study, we found that the levels of MDA were elevated in the groups administered furan at 2 and $16 \mathrm{mg} / \mathrm{kg} \mathrm{b.w./day,} \mathrm{indicating} \mathrm{the} \mathrm{induction} \mathrm{of}$ lipid peroxidation. Confirming these results, the levels of GSH and activities of antioxidant enzymes were lower in rats exposed to furan. To explore the potential of furan administration in inducing oxidative stress, besides measuring the levels of MDA and GSH we also ascertained the level of activity of CAT, GSH-Px, GST, and SOD. The observed decreases in the GSH levels and GST activity are probably due to the increased demand for GSH in the cell to combat the formation of ROS during furan metabolism. GSH can act as a nonenzymatic antioxidant with a direct interaction of the -SH group with ROS, or take part in the enzymatic detoxification reaction for ROS as a cofactor or coenzyme.

CAT activity was found to decrease in the furanadministered groups in our study, indicating the induction of hepatotoxicity. The decrease in CAT activity causes the generation of hydroxyl radicals $(\mathrm{OH} \cdot)$ derived from $\mathrm{H}_{2} \mathrm{O}_{2} \cdot \mathrm{OH} \cdot$ generation in excessive amounts also aggravates oxidative stress. The decrease in CAT activity in the liver tissue may be an adaptive response to increased levels of oxidative stress and may be attributed to interference with antioxidant functions. GSH-Px, an antioxidant enzyme, is one of the first enzymes generated as a line of defence against ROS, and a decrease is observed in its enzyme activities after furan administration. The primary reason for reduced GSH-Px activity in furan-induced oxidative stress is the inhibition of enzymatic activities by ROS. A secondary reason may be ROS binding to proteins and structural changes occurring in their structure, consequently resulting in their oxidation (47).

In the literature, several antioxidants have been investigated for their effects in preventing furaninduced toxicity in different organs and tissues $(19,21$, $36,41,42)$. Augmented antioxidant capacity is critical in providing a hepatoprotective effect and counteracts the untoward effects of oxidative stress (35). Our literature review revealed no studies investigating the antioxidant effects of propolis treatment in the furaninduced hepatotoxicity model in rats. Several studies are available, however, in the literature demonstrating these effects on several liver injury models in which the chemical insult was not furan $(7,13,22)$. Dicaffeoylquinic acid derivatives in propolis may be responsible for its antioxidative properties and may contribute to its hepatoprotective effects observed in the chemically induced models. Also in immunologically induced models, phenolic compounds in the composition of propolis may be responsible for its antioxidative actions via their radical-scavenging activities (48).

Propolis as an antioxidant source has recently received considerable attention regarding its clinical effects on thiobarbituric acid reactive substance levels $(22,30)$. Badr (4) aimed to evaluate the therapeutic effects of propolis water extract on methotrexateinduced liver toxicity in mice. The author demonstrated that the administration of propolis was associated with hepatoprotective effects against the degenerative effects of methotrexate. Bhadauria and Nirala (7) reported that ethanolic propolis extracts prevented liver damage in rats induced by overdoses of acetaminophen. The authors reported that the propolis extract had a healing effect by reversing the acetaminopheninduced changes in blood biochemical parameters, oxidative stress markers, and histopathological findings. Kolankaya et al. (23) showed that propolis was effective in preventing alcohol-induced damage. The authors reported that propolis might be protective against degenerative diseases and oxidative stress caused by alcohol. Liu et al. (25) conducted an experimental study in an acute econazole-induced liver injury model and investigated the hepatoprotective effects of propolis ethanol extract. They suggested that the significantly lower levels of MDA detected in the 
study indicated the dose-dependent inhibitory effects of propolis on lipid peroxidation. The authors concluded that the hepatoprotective effect of propolis might derive from its inhibitory effects on lipid peroxidation mechanisms, its inhibition of the synthesis of free radicals, or its scavenging effect on free-radicals. Another active component of propolis is caffeic acid phenethyl ester (CAPE). In many studies, it has been reported that CAPE is a potent agent in preventing oxidative stress in the liver for various reasons $(1,3$, 24). Ates et al. (3) demonstrated inhibition of lipid peroxidation with this molecule, reporting that CAPE reduced the degree of hepatic injury and displayed antioxidant enzyme-regulating effects. Other possible mechanisms for the hepatoprotective effects of propolis may include inhibitory effects on the synthesis of reactive metabolites via the cytochrome P450 pathway and enhanced activities of conjugation enzymes associated with detoxification (45). There is a need to gain insight into the effects of propolis on lipid peroxidation at both cell and tissue levels. An explanation at the molecular level requires demonstration of the propolis-induced changes in the cell membrane and in the activities of the enzymes involved in the lipid metabolism, including MDA.

The altered activities of some liver-specific enzymes reflect the effects of cell proliferation, and their metabolic transformations in tumour cells are quite different from normal cells (29). Many researchers have shown that furan administration causes an increase in some liver-specific enzyme activities $(29,37,43,49)$. In this study, furan administration to rats led to a marked elevation in the levels of plasma AST, ALT, ALP, and LDH, which is indicative of hepatocellular damage. This might be due to the possible rapid release of these enzymes from the cytoplasm into the circulatory system after rupture of the plasma membrane and cellular damage.

In conclusion, in our study reduced activities of antioxidant enzymes in furan-treated rats were demonstrated; however, in the group receiving the combination of propolis and furan, the MDA and GSH levels and the activities of the antioxidant enzymes and plasma AST, ALT, ALP, and LDH were found to be close to those observed in the control group. The liver MDA concentrations and improved antioxidant activities indicate that propolis plays a role in reducing oxidative stress and furan-induced damage. This can be explained by the fact that propolis has the ability to prevent oxidative stress and limit the production of free radicals, improving the antioxidant defence system. The increase in the antioxidant enzyme activities following the administration of propolis demonstrates that propolis is protective against furan toxicity and has an antioxidant role. The results also demonstrate that propolis has potential protective effects against furaninduced hepatotoxicity. Currently, more than 150 compounds have been identified in the composition of propolis. Further research is needed to identify whether some or all of its components are involved in preventing atherosclerosis, inducing hepatoprotective effects or scavenging free radicals (30).

Conflict of Interests Statement: The authors declare that there is no conflict of interests regarding the publication of this article.

Financial Disclosure Statement: This study was not supported by any donor agency.

Animal Rights Statements: The protocol for the use of animals was approved by the Firat University Animal Experiments Local Ethics Board (Elaziğ/Turkey).

\section{References}

1. Abdel-Daim M.M., Abdellatief S.A.: Attenuating effects of caffeic acid phenethyl ester and betaine on abamectin-induced hepatotoxicity and nephrotoxicity. Environ Sci Pollut Res Int 2018, 25, 15909-15917.

2. Aebi H. Catalase in vitro. Methods in Enzymol 1984, 105, 121-126.

3. Ates B., Ilker Dogru M., Gul M., Erdogan A., Dogru A.K., Yilmaz I., Yurekli M., Esrefoglu M.: Protective role of caffeic acid phenethyl ester in the liver of rats exposed to cold stress. Fundam Clin Pharmacol 2006, 20, 283-289.

4. Badr G.M.: Ameliorative effect of propolis extract on hepatotoxicity induced by methotrexate in mice. Asian J App Sci 2016, 4, 963-970.

5. Bakhiya N., Appel K.E.: Toxicity and carcinogenicity of furan in human diet. Arch Toxicol 2010, 84, 563-578.

6. Beutler E.: Red cell metabolism: A manual of biochemical methods, Grune and Starton, New York, 1984.

7. Bhadauria M., Nirala S.K.: Reversal of acetaminophen induced subchronic hepatorenal injury by propolis extract in rats. Environ Toxicol Pharmacol 2009, 27, 17-25.

8. Burka L.T., Boyd M.B.: Furans. In: Bioactivation of Foreign Compounds, edited by M.W. Anders, Academic Press, New York, 1985, pp. 243-257.

9. Clement R.E., Tosine H.M., Taguchi V., Musial C.J., Uthe J.F.: Investigation of American lobster, Homarus americanus, for the presence of chlorinated dibenzo-p-dioxins and dibenzofurans. Bull Environ Contam Toxicol 1987, 39, 1069-1075.

10. Cordelli E., Leopardi P., Villani P., Marcon F., Macrì C., Caiola S., Siniscalchi E., Conti L., Eleuteri P., Malchiodi-Albedi F., Crebelli R.: Toxic and genotoxic effects of oral administration of furan in mouse liver. Mutagenesis 2010, 25, 305-314.

11. Ding W., Petibone D.M., Latendresse J.R., Pearce M.G., Muskhelishvili L., White G.A., Chang C., Mittelstaedt R.A., Shaddock J.G., McDaniel L.P., Doerge D.R., Morris S.M., Bishop M.E., Manjanatha M.G., Aidoo A., Heflich R.H.: In vivo genotoxicity of furan in F344 rats at cancer bioassay doses. Toxicol App Pharmacol 2012, 261, 164-171.

12. Dong H., Gill S., Curran I.H., Williams A., Kuo B., Wade M.G., Yauk C.L.: Toxicogenomic assessment of liver responses following subchronic exposure to furan in Fischer F344 rats. Arch Toxicol 2016, 90, 1351-1367.

13. El Menyiy N., Al-Waili N., El Ghouizi A., Al-Waili W., Lyoussi B.: Evaluation of antiproteinuric and hepato-renal protective activities of propolis in paracetamol toxicity in rats. Nutr Res Pract 2018, 12, 535-540.

14. Ellman G.L., Courtney K.D., Andres V., Featherstone R.M.: A new and rapid colorimetric determination of acetylcholinesterase activity. Biochem Pharmacol 1961, 7, 88-95. 
15. European Food and Safety Authority (EFSA), Report of the CONTAM Panel on provisional findings on furan in food, Annex corrigendum, 2004.

16. Goldmann T., Périsset A., Scanlan F., Stadler R.H.: Rapid determination of furan in heated foodstuffs by isotope dilution solid phase micro-extraction-gas chromatography-mass spectrometry (SPME-GC-MS). Analyst 2005, 130, 878-883.

17. Habig W.H., Pabst M.J., Jakoby W.B.: Glutathione S-transferases. The first enzymatic step in mercapturic acid formation. J Biol Chem 1974, 249, 130-139.

18. Hamadeh H.K., Jayadev S., Gaillard E.T., Huang Q., Stoll R., Blanchard K., Chou J., Tucker C.J., Collins J., Maronpot R., Bushel P., Afshari C.A.: Integration of clinical and gene expression endpoints to explore furan-mediated hepatotoxicity. Mutat Res 2004, 549, 169-183.

19. Hickling K.C., Hitchcock J.M., Oreffo V., Mally A., Hammond T.G., Evans J.G., Chipman J.K.: Evidence of oxidative stress and associated DNA damage, increased proliferative drive, and altered gene expression in rat liver produced by the cholangiocarcinogenic agent furan. Toxicol Pathol 2010, 38, 230-243.

20. International Agency for Research on Cancer (IARC). Monographs on the evaluation of carcinogenic risks to humans. Dry cleaning, some chlorinated solvents and other industrial chemicals, 63. IARC, Lyon 1995, pp. 3194-3407.

21. Kara O.: Toxicity of furan on testis in diabetic rats and protective role of lycopene, Master Thesis, Bozok University/Graduate School of Natural and Applied Sciences/Department of Biology, promoter D. Pandir, 2015.

22. Kaya E., Yılmaz S., Çolakoğlu N.: The protective role of propolis in cyclophosphamide-induced cardiotoxicity in rats. Ankara Üniv Vet Fak Derg 2019, 66, 13-20.

23. Kolankaya D., Selmanoğlu G., Sorkun K., Salih B.: Protective effects of Turkish propolis on alcohol-induced serum lipid changes and liver injury in male rats. Food Chem 2002, 78, 213-217.

24. Li M., Wang X.F., Shi J.J., Li Y.P., Yang N., Zhai S., Dang S.S.: Caffeic acid phenethyl ester inhibits liver fibrosis in rats. World J Gastroenterol 2015, 21, 3893-3903

25. Liu C.F., Lin C.H., Lin C.C., Lin Y.H., Chen C.F., Lin C.K., Lin S.C.: Antioxidative natural product protect against econazole-induced liver injuries. Toxicol 2004, 196, 87-93.

26. Lowry O.H., Rosebrough N.J., Farr A.L., Randall R.J.: Protein measurement with the Folin phenol reagent. J Biol Chem 1951, 193, 265-275.

27. Luna L.G.: Manual of histologic staining methods of the Armed Forces Institute of Pathology. McGraw-Hill, New York, 1968. pp. $1-36$

28. Maronpot R.R., Giles H.D., Dykes D.J., Irwin R.D.: Furaninduced hepatic cholangiocarcinomas in Fischer 344 rats. Toxicol Pathol 1991, 19, 561-570.

29. National Toxicology Program (NTP), Toxicology and carcinogenesis studies of furan in F344 rats and B6C3F1 mice (gavage studies). NTP Technical Report No. 402, 1993.

30. Pascual C., Gonzalez R., Torricella R.G.: Scavenging action of propolis extract against oxygen radicals. J Ethnopharmacol 1994, 41, 9-13.

31. Perez-Locas C., Yaylayan V.A.: Origin and mechanistic pathways of formation of the parent furan - a food toxicant. J Agric Food Chem 2004, 52, 6830-6836.

32. Peterson L.A., Cummings M.E., Chan J.Y., Vu C.C., Matter B.A.: Identification of a cis-2-butene-1, 4-dial-derived glutathione conjugate in the urine of furan-treated rats. Chem Res Toxicol 2006, 19, 1138-1141.
33. Placer Z.A., Cushman L., Johnson B.C.: Estimation of products of lipid peroxidation in biological fluids. Anal Biochem 1966, $16,359-364$.

34. Ploch S.A., Kedderis G.L.: Formation of DNA double-strand breaks in F-344 rat liver following in vivo exposure to furan. In: The Toxicologist, supplement to Toxicological Sciences, Society of Toxicology, 2001, Abstract 735, 154.

35. Pushpavalli G., Veeramani C., Pugalendi K.V.: Influence of Piper betle on hepatic marker enzymes and tissue antioxidant status in D-galactosamine-induced hepatotoxic rats. J Basic Clin Physiol Pharmacol 2008, 19, 131-150.

36. Saracoğlu G.: Furan induced cardiotoxicity in diabetic rats and protective role of lycopene, Master Thesis, Bozok University/Graduate School of Natural and Applied Sciences/Department of Biology, promoter D. Pandir, 2016.

37. Selmanoğlu G., Karacaoğlu E., Kılıç A., Koçkaya E.A., Akay M.T.: Toxicity of food contaminant furan on liver and kidney of growing male rats. Environ Toxicol 2012, 27, 613-622.

38. Sprankle C.S., Goldsworthy T.L., Goldsworthy S.M., Wilson D.M., Butterworth B.E.: Expression of the hepatocyte growth factor and c-MET genes during furan-induced regenerative cell proliferation in the livers of $\mathrm{B} 6 \mathrm{C} 3 \mathrm{~F} 1$ mice and F-344 rats. Cell Prol 1994, 27, 529-539.

39. Sun Y., Oberly L.W., Ying L.A.: Simple method for clinical assay of superoxide dismutase. Clin Chem 1988, 34, 497-500.

40. Takino Y., Mochida S.: Propolis: its chemical constituents and biological activities. Honeybee Sci 1982, 3, 145-152.

41. Ucar S.: Furan induced ovarian toxicity in diabetic rats and protective role of lycopene, Master Thesis, Bozok University/Graduate School of Natural and Applied Sciences/Department of Biology, 2017.

42. Unal B.: Furan induced nephrotoxicity in diabetic rats and protective role of lycopene, Master Thesis, Bozok University/Graduate School of Natural and Applied Sciences/Department of Biology, 2016.

43. Wang E., Chen F., Hu X., Yuan Y.: Protective effects of apigenin against furan-induced toxicity in mice. Food Funct 2014, 5, 1804-1812.

44. Wilson D.M., Goldsworthy T.L., Popp J.A., Butterworth B.E.: Evaluation of genotoxicity, pathological lesions, and cell proliferation in livers of rats and mice treated with furan. Environ Mol Mutagen 1992, 19, 209-222.

45. Won Seo K., Park M., Jung Song Y., Kim S.J., Ro Yoon K.: The protective effects of propolis on hepatic injury and its mechanism. Phytother Res 2003, 17, 250-253.

46. World Health Organization: Polychlorinated dibenzo-paradipoxins and dibenzofurans Environmental Health Criteria 88, International Programme on Chemical Safety. Geneva, Switzerland, 1989

47. Yilmaz S., Kaya E., Kisacam M.A.: The effect on oxidative stress of aflatoxin and protective effect of lycopene on aflatoxin damage. In: Aflatoxin-Control, Analysis, Detection, and Health Risks, edited by L. Abdulra'Uf, London, 2017, pp. 67-90.

48. Yilmaz S., Tatli Seven P., Kaya E.: Effects of propolis, royal jelly, bee pollen and ronozyme supplementation in diets of Japanese quails (coturnix coturnix japonica) on yolk lipid peroxidation. Int J Vet Health Sci Res 2017, 5, 183-189.

49. Yuan Y., Wu S.J., Liu X., Zhang L.L.: Antioxidant effect of salidroside and its protective effect against furan-induced hepatocyte damage in mice. Food Funct 2013, 4, 763-769. 